\title{
Attitude Towards Islam and Women in Hijabs in South Russia
}

\author{
Daria V. Pogontseva
}

Southern Federal University, Russia, 344006, Rostov-on-Don, Bolshaya Sadovaya str. 105/42

Email:dpogontseva@gmail.com

\section{Doi:10.5901/mjss.2015.v6n6s1p438}

\begin{abstract}
The paper considers the peculiarities especially the formation of attitudes towards women, in connection with the ethnoreligious characteristics of the processing of their appearance (for example, hidjab (Islamic head-cover)). The object of the study were 106 people, 56 women and 50 men aged 22 to 30 years (mean age 27 years), residents of the city of Rostov-onDon, Russia. This age group was chosen due to the fact that young people are the most susceptible to influence and manipulation group. The study used a "Scale of hostility" Cook-Medley (method translated and adapted by Yu.A.Mendzheritskaya), as well as the author's questionnaire, which consisted of stimulus material (2 sets of photos of 5 girls in one case it was a portrait shot from the front with natural make-up, a second set - the same girls, but in black hijab), respondents were asked to estimate the ratio of the girls in the photographs shown on a scale from friendly to hostile. Based on the results we can say that the level of aggression can lead to a negative, hostile attitude towards the Muslim girl (based only on the design of the external appearance), besides more men evaluate their attitude to the girls wearing the hijab as hostile.
\end{abstract}

Keywords: hijab, female, attitude, clothing behavior

\section{Introduction}

Recent events led to the emergence of sustainable phrase "Islamic factor". Starting from the terrorist attacks in Moscow, Stavropol region, in different regions of the North Caucasus and ending with the conflict with the Islamic state and the terrorist attack in France at the editorial office of "The Charlie Hebdo" this theme (the relationship with the Islamic world) has been brought up in various works on political science, conflict studies, sociology, philosophy and psychology. Elashi F.B. et al. (2010) noted that negative stereotypes towards Muslims escalated after the events of September 11th. So $11 / 09$ event was a turning point of formation attitude towards Islam all over the world. However, considering the history of the South of Russia, it is important to note that the proximity to the republics of the North Caucasus, as well as trade and economic and political ties provided interaction between people of different nationalities and religions. In this situation, the categorization of "the other" in appearance comes to the fore. And as noted by V.A. Labunskaya (2013) appearance is becoming one of the most important means of building typologies, allocation and recognition of certain social groups, strata, describing life-styles. ... The appearance of a man becomes a way of visual communication and stratification. At the same time, the urgency of the problem of hijab in Russia began to grow after the conflict in the Stavropol region (2012), when Muslim girls started wearing a scarf to school. And the last one - conflict at the border with a Russian girl aiming to join the Islamic State of Iraq and the Levant (June 2015).

\section{Literature Review}

Discrimination based on physical appearance is a pervasive social problem all over the world. Revealing the essence of the hijab O.V. Tarasenko (2010) emphasizes that under the hijab headscarf the most mean exclusively women, but this concept is broader and includes "external hijab" (clothing covering the entire body except the face and hands) and 'internal hijab "(beliefs, behaviors). Inside the hijab, as the author states is "life position Haya - modesty, shyness, shyness." In turn, M.G. Dosanova (2010), studying the attitude of modern girls who wear hijab, revealed that one of the main reasons for women in Kazakhstan to do so is to claim a certain status or position. For many girls, hijab is a chance to get married faster, to be accepted in certain social groups, to use religion as a specific resource, in addition, hijab is a way to represent themselves as those "having the knowledge of what should be a real woman." Thus, the author emphasizes that for the majority of respondents (women aged 17 to 35) hijab is a way to achieve not only religious purposes as secular. Hassim N. (2014) note that the globalization of Islamic worldwide inadvertently changed the representation of Muslim woman and hijab. In another work Y. Mahmud and V. Swami (2010) examined the effects of 
wearing hijab on men's perceptions of women's attractiveness and intelligence. They noticed that there is a significant effect of hijab status, with women wearing hijab being rated more negatively than unveiled women. On the background of of interest in the phenomenon of hijab can be noted http resource: worldhijabday.com, the basic position is "before you judge - cover up for a day". This resource includes stories of more than 19 thousand women from different parts of the world of their sensations, feelings and experiences related to the wearing of hijab.

In some works (Brown L., Brown J. 2015; McDermott-Levy R. 2011, Ho C. 2007,) categorization of the "other" and the role of appearance as a ethnic discrimination. However, according to some studies, in countries where the number of immigrants is not high, discrimination is at the level of "alien" starts from kindergarten (Wagner J.T., 2008). Jelen, B. (2011) show that in Turkey today, young university-educated hijabi are aspiring to higher education, professional careers, as well as more equal gender relations at work and at home. She noted that this female are a pioneer generation. It should be noted that the problem of immigration and categorizing immigrants by appearance is a key issue for almost all European countries, Canada and Ausralia. It is also applicable to Russian reality and well reflected in the categorization of "tajik" - all immigrants from Central Asia, as well as the categorization of all the peoples of the Caucasus as "persons of Caucasian nationality", and attributing them (the inhabitants of the Caucasus). Islam is the main religion, and despite the the fact that a large part of the population is Muslim Caucasus - some regions are traditionally Christian (Abkhazia, Georgia, Armenia it.d.). The Russian Constitution in the 19th article stipulates that the state guarantees equal rights and freedoms of men and citizen, regardless of gender, race, nationality, language, origin, property and official status, place of residence, attitude to religion, convictions, membership of public associations as well as other factors (Pogontseva D.V., 2013). Thus, the law prohibits any form of restriction of the rights of citizens on social, racial, national, linguistic or religious identity, while at the same time using a variety of stereotypical judgments we divide people into groups according to appearance, but each of these groups confers certain characteristics that may be how to fit this group, and to be false.

In modern psychology there are a lot of works about role of hijab in nonmuslim countries (Webster, S.K. 1984, Ruby T. F. 2006, Chaker Z. et al.2015, Brown, K. 2006, El-Geledi, S. and Bourhis, R.Y. 2012, Mirza, H. S. 2013 and so on), but there are not enough works about Russian attitude toward hijab as a symbol of muslim.

\section{Research Methodology}

\subsection{Participants}

106 people, 56 women and 50 men aged 22 to 30 years (mean age 27 years), all of them are residents of the city of Rostov-on-Don, Russia. Youth - the socio-demographic group, released on the basis of the aggregate of age characteristics, features of the social situation and the specific social and psychological qualities, different authors identify age limits in different ways, but we can say that in general, it is the period between childhood and adulthood, and in our study we took a broad framework from 18 to 30 years. Thus, the current situation in Russia and in the world dictates an increased interest in the study of young people, as the most vulnerable to influence and manipulation group. All respondents are students and staff from different schools and universities. This choice is due to the fact that these groups interact with representatives of various religious confessions every day.

\subsection{Instrument}

To study the peculiarities of perception of women in connection with the registration of their ethnic appearance, we have prepared two sets of photos of 5 girls in one case it was a portrait shot from the front with a natural make-up, a second set - the same girl, but with black hijab. Photographs of girls without headscarves were coded 1-5, 6-10 in hijabs in turn 1 and 6 pictures - the same girl. Pictures were presented in black and white, it was done in order to neutralize the hair and eye color. The participants have to rate each photo with a scale from friendly to hostile, friendly coded as 1 and hostility as the 6 points, so the lower the average score the more friendly attitude. Each picture was displayed on a separate sheet of $A 5$, pictures were presented in random order, to monitor only one and the same woman (wearing the hijab or not) is not demonstrated in a row. 


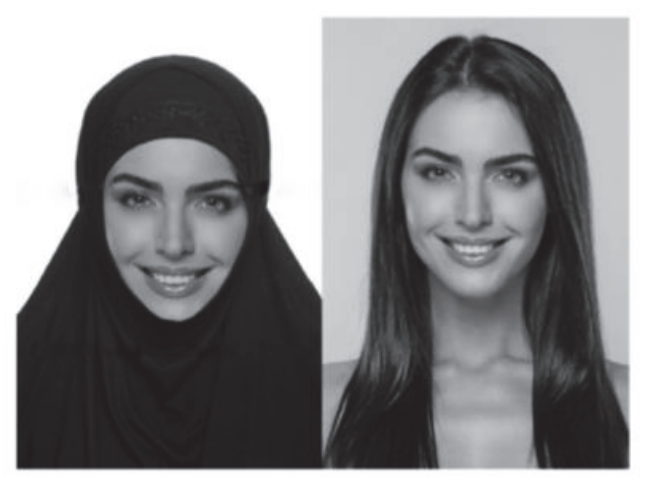

Figure 1. Example photo of a girl in hijab and without

The same respondents were asked to fill out "the scale of hostility" Cook-Medley (method translated and adapted to Russian by Yu.A.Mendzheritskaya (2001), designed to measure the intensity of the relationship of hostility, aggression and suspicion. The methodology contains 27 statements. Participants need to express their attitude to these statements, using a scale that has 6 grades: "always", "often", "sometimes", "accident", "rarely", "never". The data was analyzed using the Statistical Package for the Social Sciences (SPSS Version 16.0 for Windows) and Statistica 7.0. The reliability of the data provided using the following methods of mathematical statistics: Z-Wilcoxon test to determine a statistically significant shift, Spearman correlation coefficient to identify relationships between variables; U-Mann-Whitney test to detect differences between samples.

\section{Findings and Discussion}

In the first phase we compared the results of the responses of men and women, so we used the Mann-Whitney $U$ test. We have identified a number of significant differences, since the indicator "cynicism" is higher in women $(U=-2,11$, at $p$ $<0,05)$ while the index of "aggressiveness" was significantly higher in men $(U=2,19$, at $p<0,05)$, at the same time on the scale of hostility significant differences were found, and the average in the sample - below average.

There were also found significant differences in assessing the photos, it should be noted that the ratio of the girls shown in the photo were coded 1-friendly, 9-hostile, so the higher the average score, the more negative attitude was by respondents. It is interesting to note that the average score suggests that the attitude to girls without a hijab friendly (MF1 $=3.1 ; \mathrm{MF}=2.2 ; \mathrm{MF}=2.3, \mathrm{MF} 4=2.5 ; \mathrm{MF5}=3.7$ ), the ratio of the girls in hijab rather negative attitude (MF6 = 5.8; MF7 = $5.15 ;$ MF8 $=5.32$; MF10 $=5.8$ ), in addition to the portrait 9 (MF9 = 3.9), which is often estimated as more friendly. When rating the portrait of a girl with a typical Slavic appearance (round face, blond hair, big blue eyes) in hijab several respondents asked «why is there a portrait of nun among the Muslim girls?», so black headscarf some respondents regarded "not as hijab", due to the appearance of the girl. The girl on the picture 5 (woman without hijab) was described by most respondents as "artful, stressful and unpleasant" that can be attributed to stressful look (narrowed eyes, tightly shut lips, etc.) so her ratio was the most hostile. In general, women more frequently evaluated portraits as more friendly, since significant differences were obtained to assess the girl in the picture $3(U=2,01$; when $p<0,05$; woman without hijab), picture $4(U=4,06 ; p$ at $<0.05$; woman without hijab), picture $6(Z=3,17$; when $p<0,05$; woman in hijab), picture 8 $(U=2,41$; when $p<0,05$; woman in hijab ), picture $9(U=3,44$; when $p<0,05$; woman in hijab) (table 1).

Table 1. Mann-Whitney U Test between men and woman

\begin{tabular}{|c|c|}
\hline Variable & Marked tests are significant at $p<0,05$ \\
\hline Cynicism & $-2,11110$ \\
\hline Agressiveness & 2,19325 \\
\hline Hostility & $-1,95503$ \\
\hline picture 1 & $-0,27108$ \\
\hline
\end{tabular}




\begin{tabular}{|c|c|}
\hline picture 2 & 1,61824 \\
\hline picture 3 & 2,01253 \\
\hline picture 4 & 4,06613 \\
\hline picture 5 & $-1,04323$ \\
\hline picture 6 & 3,28576 \\
\hline picture 7 & $-0,22179$ \\
\hline picture 8 & 2,25075 \\
\hline picture 9 & 0,50108 \\
\hline picture 10 & 3,44183 \\
\hline
\end{tabular}

The results of the correlation analysis (table 2), in turn, suggests that the level of cynicism does not affect the relation to another person at the same time, the level of aggression has a direct correlation with the formation of a negative attitude, we found an association with the evaluation index of aggressiveness photo 5 (woman without hijab) $(r=0,27$; when $p$ $<0,05)$, as well as pictures $6(r=0,46$; when $p<0,05), 7(r=0,28$; when $p<0,05), 8(r=0,54$; at $p<0,05), 9(r=0,29$; at $p$ $<0,05), 10(r=0,40$; at $p<0,05)$ - which depict women wearing the hijab.

Table 2. Correlations level of age, aggression, cynicism and hostility and the attitude of the girls in the picture

\begin{tabular}{|l|c|c|c|c|c|c|c|c|c|c|}
\hline & \multicolumn{10}{|c|}{ Correlations. Marked correlations are significant at $\mathrm{p}<, 05000 \mathrm{~N}=106$} \\
\hline Variable & $\mathrm{F} 1$ & $\mathrm{~F} 2$ & $\mathrm{~F} 3$ & $\mathrm{~F} 4$ & $\mathrm{~F} 5$ & $\mathrm{~F} 6$ & $\mathrm{~F} 7$ & $\mathrm{~F} 8$ & $\mathrm{~F} 9$ & $\mathrm{~F} 10$ \\
\hline Age & 0,0736 & $\mathbf{0 , 3 2 9 5}$ & $\mathbf{0 , 2 7 1 3}$ & 0,0996 & $-0,0880$ & 0,0773 & $-0,0259$ & $\mathbf{0 , 3 2 2 4}$ & 0,2541 & 0,0074 \\
\hline Cynicism & 0,0692 & 0,1766 & 0,0179 & $-0,1176$ & 0,0753 & $-0,1369$ & $-0,0862$ & $-0,2097$ & $-0,1848$ & $-0,1908$ \\
\hline Agressiveness & 0,2128 & 0,0222 & 0,0818 & 0,1250 & $\mathbf{0 , 2 7 1 1}$ & $\mathbf{0 , 4 6 5 2}$ & $\mathbf{0 , 2 8 5 8}$ & $\mathbf{0 , 5 4 6 9}$ & $\mathbf{0 , 2 9 9 1}$ & $\mathbf{0 , 4 0 8 4}$ \\
\hline Hostility & $\mathbf{0 , 4 1 8 3}$ & 0,2159 & $\mathbf{0 , 4 7 1 5}$ & 0,1911 & $\mathbf{0 , 5 5 3 2}$ & 0,1606 & 0,0830 & 0,1195 & 0,2413 & $-0,0787$ \\
\hline
\end{tabular}

We also used the Z-Wilcoxon test to identify whether there are significant differences in the evaluation of the same girls in headscarves and without it. We have found significant differences in all five cases (Table 3). Our findings on the line indicate that there are influence design appearance on the formation of relationships. Despite the fact that there is a certain range of relationships to the girls in hijab and without it the attitude to the girl in hijab is worse than to the same girl with uncovered head.

Table 3. Wilcoxon Matched Pairs Test between the same girls in hijab and without (Marked tests are significant at $p$ $<0,05)$

\begin{tabular}{|c|c|}
\hline Pair of Picture & Z \\
\hline Picture1 \& Picture6 & 5,333278 \\
\hline Picture2 \& Picture7 & 5,579595 \\
\hline Picture3 \& Picture8 & 5,570407 \\
\hline Picture4 \& Picture9 & 3,682860 \\
\hline Picture5 \& Picture10 & 3,674098 \\
\hline
\end{tabular}

\section{Concluding Remarks}

Our findings on the line indicate that there are influence design appearance on the formation of relationships. Despite the fact that there is a certain range of attitude to the girls in hijab and without it the girl in hijab attitude is worse than to the same girl with uncovered head.

Based on the results, we can conclude that the level of aggression can lead to a negative, hostile attitude towards the Muslim girl (based solely on the design of the appearance), besides more men evaluate their attitude to the girls wearing hijab as a more hostile. One of our results also indicates that the attitude can affect both personal stereotypes (as evidenced by evaluation of women without hijab, closer to the median performance and some negative assessment) and difficulties in the categorization (eg, evaluation of pictures 9 when rated as the hijab attire nuns).

In general, despite the fact that the Southern Federal District - multicultural, and the proximity of Islamic peoples of the Caucasus forms a certain neutral attitude to the representatives of various religions, women with Slavic appearance 
dressed in traditional Islamic headgear - are perceived significantly more hostile than the same women without a scarf. If considering this issue more widely, we can note that in this case there was triggered a certain layering of assessments on the one hand - the girl and the assessment of the attractiveness of the girls attributing certain characteristics, and on the other hand - the categorization and discrimination against women with a certain design appearance. However, considering the problem of Islamophobia in Russia and comparing the attitude towards Islam in Europe, North America and Australia, we can assume that the factor of rapprochement of cultures has a positive effect. Experience, such as Tatarstan muslim generates more positive setting to all representatives of Islam, which could also explain the results.

Thus, the aim of our future work, we see an increase in the sampling and testing hypotheses about the relationship level of hostility and aggressiveness on the formation of attitude to girls with "European" and "Muslim" appearance design. In the future, in addition to photos without a hijab and hijab we plan to add pictures of girls in colored scarves (scarf tied under the chin in the "Russian" style) and the girls in typical headgear of Christian (Catholic) nuns since these scarves and hats are similar in nature - open face, hair and neck are covered, but are connected to different stereotypes. And to identify attitudes towards Islam in general and the role of the attitude towards Islam in the formation of attitudes towards girls in hijab we also believe it is necessary to develop a profile filter to determine the religious beliefs of the respondents, as in the pilot study involved young people as believers (Orthodox), and to adopt atheistic beliefs, but there were no respondents who practice Islam. At the same time, a number of works indicate that such differences may be detected. It is also important to note that the assessment can provide color and the presence - absence of ornament and pattern on the hijab. So we can assume that the hijab with flower pattern, bright colors can positively influence the attitude of the girls. Another important point, which we plan to explore - this is the age of women wearing the hijab. In our study, the photograph shows girls 20-25 years, in future we plan to use the photos of women aged 45-60 years, which may be associated with the "mother", because in Russian tradition of older women wearing headscarves in the Church (Christian), and in everyday life, so to older women in hijab can be a more positive attitude.

\section{Acknowledgements}

The study was sponsored by the SFU (grant "threats to national security in the conditions of geopolitical competition and models of aggressive and hostile behavior of youth" theme № 213.01-07-2014 / 15PCHVG (internal grant project of the Southern Federal University).

\section{References}

Brown L., Brown J., Richards B. (2015) Media representations of Islam and international Muslim student well-being. International Journal of Educational Research, 69, 50-58. doi:10.1016/j.jijer.2014.10.002

Brown, K. (2006) Realising Muslim women's rights: The role of Islamic identity among British Muslim women. Women's Studies International Forum, 29(4), 417-430. doi:10.1016/j.wsif.2006.05.002

Bzezyan A.A. (2014) Osobennosti etnicheskoy identichnosti kak prediktor prinyatiya diskriminatsionnogo otnosheniya $k$ etnokul'turnym gruppam // Natsional'naya bezopasnost' / nota bene.-2014.-3.-C. 454-464. DOI: 10.7256/2073-8560.2014.3.12083.

Chaker, Z., Chang, F. M., Hakim-Larson, J. (2015) Body satisfaction, thin-ideal internalization, and perceived pressure to be thin among Canadian women: The role of acculturation and religiosity // Body Image, 14, 85-93. doi:10.1016/j.bodyim.2015.04.003

Dunkel, T. M., Davidson, D., Qurashi, S. Body satisfaction and pressure to be thin in younger and older Muslim and non-Muslim women: The role of Western and non-Western dress preferences. Body Image, 7(1), 56-65. doi:10.1016/j.bodyim.2009.10.003

Elashi, F. B. Mills, C.M. Grant, M.G. (2010) In-group and out-group attitudes of Muslim children. Journal of Applied Developmental Psychology, 31(5), 379-385

El-Geledi, S. and Bourhis, R.Y. (2012) Testing the impact of the Islamic veil on intergroup attitudes and host community acculturation orientations toward ArabMuslims. International Journal of Intercultural Relations, 36(5), 694-706. doi:10.1016/j.ijintrel.2012.03. 006

Hanniman W. (2008) Canadian Muslims, Islamophobia and national security. International Journal of Law, Crime and Justice, 36(4), 271-285. doi:10.1016/.jijlci.2008.08.003

Hassim N. (2014) Hijab and the Malay-Muslim Woman in Media. Procedia - Social and Behavioral Sciences, Volume 155, Pages 428433. doi:10.1016/j.sbspro.2014.10.317

Ho C. (2007) Muslim women's new defenders: Women's rights, nationalism and Islamophobia in contemporary Australia. Women's Studies International Forum. 30(4), 290-298. doi:10.1016/j.wsif.2007.05.002

Jelen, B. (2011) Educated, independent, and covered: The professional aspirations and experiences of university-educated hijabi in contemporary Turkey Women's Studies International Forum, 34(4), 308-319. doi:10.1016/j.wsif.2011.04.008

Labunskaya, V.A. (2013) Representations about Friend and Enemy at Different Life-span Stages. Procedia - Social and Behavioral Sciences, 86, 256-261. doi:10.1016/j.sbspro.2013.08.560

Labunskaya, V.A., Mendzheritskaya, Yu.A., Breus, E.D. (2010) Psikhologiya zatrudnennogo obshcheniya: Teoriya. Metody. Diagnostika. 
Korrektsiya. Uchebnoe posobie dlya studentov vysshikh uchebnykh zavedeniy. Moscow.

Mahmud, Y., Swami, V. (2010) The influence of the hijab (Islamic head-cover) on perceptions of women's attractiveness and intelligence. Body Image, 7(1), 90-93. doi:10.1016/j.bodyim.2009.09.003

McDermott-Levy, R. (2011) Going alone: The lived experience of female Arab-Muslim nursing students living and studying in the United States. Nursing Outlook, 59(5), 266-277. doi:10.1016/j.outlook.2011.02.006

Mirza, H. S. (2013) 'A second skin': Embodied intersectionality, transnationalism and narratives of identity and belonging among Muslim women in Britain. Women's Studies International Forum, 36, 5-15. doi:10.1016/j.wsif.2012.10.012

Pogontseva, D.V. (2013) Vidy diskriminatsii po vneshnemu obliku. Psikhologiya i Psikhotekhnika. 9. 858-861. DOI: 10.7256/2070-8955. 2013.9.9106.

Ruby, T. F. (2006) Listening to the voices of hijab.Women's Studies International Forum, 29(1), 54-66. doi:10.1016/j.wsif.2005.10.006

Wagner, J. T, Camparo, B., Tsenkova, V., Camparo, J. C. (2008) Do anti-immigrant sentiments track into Danish classrooms? Ethnicity, ethnicity salience, and bias in children's peer preferences. Intern. J. of Educ. Research. 47(5). 312-322. doi:10.1016/j.ijer. 2008.12.003

Webster, S.K. (1984) Harim and Hijab: Seclusive and exclusive aspects of traditional Muslim dwelling and dress. Women's Studies International Forum, 7(4) 251-257 doi:10.1016/0277-5395(84)90050-5 